\title{
Az oklevelek kevert nyelvi állapotáról a nyelvjárástörténeti vizsgálatok tükrében*
}

1. A nyelvjárástörténeti vizsgálatok elsődleges, közvetlen forrásanyagát az ómagyar kortól kezdődően több más egyéb fogódzó mellett a nyelvemlékekben fellelhető nyelvi adatok jelentik. A nyelvemlékek adatainak nyelvjárástörténeti forrásértéke azonban nagyon különböző lehet, ahogyan erröl egy korábbi munkámban már szóltam (BÁBA 2018). Mostani írásomban e szerteágazó kérdéskörnek csak egy aspektusára, az oklevelek kevert nyelvi állapotára és ennek a nyelvjárástörténeti kutatások során is figyelembe veendő szerepére kívánok kitérni.

BENKÖ LORÁND a nyelvemlékek felhasználásának legfőbb korlátját abban látja, hogy „nincs olyan nyelvemlékünk (leszámítva talán a pár szavas vagy soros apróságok némelyikét), amelyben teljesen egységes, következetes nyelvállapot tárulna elénk" (1957: 37). Az egyes nyelvemlékekben tapasztalható ingadozások véleménye szerint származhatnak az író saját nyelvállapotának és az írásbeli standardnak a keveredéséből, az író saját nyelvállapotának normahatásoktól független ingadozásaiból, illetve különböző egyének nyelvállapotának együttes jelenlétéből (1957: 37-44). Az ómagyar kori oklevelek adatainak nyelvjárástörténeti hasznosításakor ezekre a szempontokra természetesen éppúgy figyelemmel kell lennünk, mint bármely későbbi nyelvemlék ilyen célú vizsgálatakor.

2.1. Számos nyelvemlékünk kevert nyelvi állapotát az explicit módon leginkább csak a 15-16. század fordulója után megjelenő normatív szokások eredményezik (BÁRCZI 1967/2002: 16, KISS J. 2018: 362). Ez azzal van összefüggésben, hogy a formálódó írásos hagyomány legtöbbször csak részben tudja elnyomni a szerző saját nyelvi állapotát, ami nagyszámú ingadozáshoz, sőt nem egy esetben téves visszaütéshez vezet (BENKŐ 1957: 39-42). ${ }^{1}$ Ezek a normatív szokások BENKÖ LORÁND szerint a 16. századtól kezdődően (vagyis a jelentősebb értelmiségi réteg megjelenéséhez köthetően, lásd ehhez még KOROMPAY 2003: 579) a

\footnotetext{
* A tanulmány az MTA Prémium Posztdoktori Kutatóprogram keretében készült (befogadó intézmény: Debreceni Egyetem).

${ }^{1}$ Ez utóbbiak mellesleg kiváló terepet biztosítanak az eredeti nyelvjárási formára való visszakövetkeztetésre (lásd ehhez BENKÖ 1957: 41-42, JUHÁSz 2018: 337).
} 
grammatikákban és az ortográfiákban egyre inkább kezdenek határozottabban is testet ölteni.

A nyelvjárások fölötti változat mindinkább hangsúlyos jelenlétét a középmagyar korban a magyar nyelvü írásbeliség térnyerése és a könyvnyomtatás fokozatos elterjedése mellett a nyelvterület közepén zajló természetes integrációs, kiegyenlítődési folyamatok is elősegítették (KOROMPAY 2003: 584, JUHÁSZ 2018: 333). Ennek ellenére a nyelvjárási sajátosságok és az írásbeli standard érvényesülésének az aránya az egyes írásmúvekben még ebben a korban is több tényező függvénye: a színterektől, alkalmaktól és szövegmüfajoktól éppúgy függ a nyelvjárásiasság mértéke, mint ahogyan természetesen az egyes nyelvhasználók, az írók, deákok nyelvi attitüdje (ami szintén több összetevő eredménye lehet) ${ }^{2}$ is jelentős befolyásoló szereppel bír ebben a tekintetben (JUHÁSZ 2018: 333).

2.2. Bár a magyar írott köznyelv tényleges egységesülésének kezdetét KISS JENÖ véleménye szerint is a 16. századtól számíthatjuk, úgy véli, hogy ennek a hosszú folyamatnak a „,kezdete a magyar írásbeliség megjelenése volt. Az írásnak ugyanis nemcsak konzerváló, hanem mintaadó, azaz követésre késztető szerepe volt mindig" (2018: 362). Ilyen értelemben pedig ő maga az ómagyar kort az írott nyelvi egységesülés szempontjából az előzmények koraként tárgyalja (2018: 361).

Mivel pedig a latin betüs magyar nyelvü írásbeliség kialakulása a latin nyelvü szövegek fordításához szorosan kötődik, természetes, hogy a korai írásszokások elsősorban a latin nyelv erőteljes hatásának tulajdoníthatók. BENKÖ LORÁND és BÁRCZI GÉZA például korai írásszokással magyarázza a fordításokban (és részben az eredeti magyar szövegekben is) megjelenő igemódoknak és -időknek meghatározott szabályokhoz igazodó, latinos használatát, a latin igeneves szerkezetek szolgai módon történő fordítását, a kettős kapcsolású birtokos jelzős szerkezetek kedvelését (a háznak a teteje forma a ház teteje formával szemben), a számnévi jelző utáni többes szám (pl. hét fö bünök) vagy a páros testrészek nevének többes számú használatát (pl. kezeivel) (BENKŐ 1957: 39-42, BÁRCZI 1963/1975: 186187, 1967/2002: 521). A latin nyelv hatása ugyanakkor persze nem egyforma mértékben jelentkezik az egyes fordítók szövegeiben, így például a Guary-kódex és a Sándor-kódex kiváló nyelvérzékkel fordított munkák, szemben azokkal az írásművekkel, amelyek az eredeti latin mondatok szerkesztésmódjához a szöveg érthetőségének az árán is ragaszkodnak (BÁRCZI 1963/1975: 187). Az itt felsorolt példák alapján BÁRCZI GÉZA úgy látja, hogy a korszakban kialakulóban van az írástudók tudatában a nyelvi helyesség és helytelenség fogalma, vagyis egyfajta

\footnotetext{
2 Így például abban, hogy Sylvester János minden munkájában szinte korlátozás nélkül érvényesül az erős $i$-zés, valószínúleg szerepe lehetett a Szatmár megyei származásán és lokálpatriotizmusán túl annak is, hogy életének másik színtere, Sárvár ugyancsak $i$-ző területen található, és a két régió $i$-zése nem tér el jelentősen egymástól (JuHÁsz 2018: 333).
} 
nyelvi norma kezd kibontakozni, amely ,,a beszélt nyelvi mondattal szemben egy külön, írott nyelvi latinos mondattant követel, és bizonyos nyelvjárási jelenségeket kirekeszt" (1963/1975: 188). Joggal vetődik fel azonban a kérdés, különösen a korai ómagyar kori szövegemlékekkel való összevetésben, hogy az eredeti latin szöveghez való szigorú ragaszkodás, annak szolgai módon történő fordítása menynyiben tekinthető a normahatások érvényesülésének. Az Árpád-kori kis szövegemlékekről BENKŐ LORÁND ugyanis azt állapítja meg, hogy azok mondatszerkesztési eljárásai valószínüleg sokkal inkább megfelelnek a magyar mondatalkotási szokásoknak, vagyis ezek a nyelvemlékek még abban az időszakban keletkeztek, amikor a latinizálási kényszernek nem esett áldozatul a magyar írásbeliség (1980: 367). ${ }^{3}$ Ez szoros összefüggésben van azzal, hogy az Árpád-kori szövegemlékek a beszédbeli felhasználás igényével készültek, míg a kései ómagyar kor vallásos szövegei „az olvasmány-ellátottság kielégítését célozták” (1980: 31).

A szövegek normasajátosságaira való kitekintés témánk szempontjából még több hozadékkal járhat, ha az ilyen, elsősorban mondatszerkesztési sajátosságok mellett bizonyos hangtani jegyekre is figyelmet fordítunk. Igaz ugyan, hogy BÁRCZI GÉZA szerint a hangtani és alaktani szempontból is egységes írott nyelv kialakulása késlekedik a korban, ${ }^{4}$ mégis úgy látja, hogy az ómagyar kor végén két olyan nyelvváltozat kibontakozása is útjára indul, amely hangtani szempontból is a nyelvi egységesülés irányába mutat. Az egyik az általa „kolostori nyelv”-nek nevezett típus, amelyre az $\ddot{o}$-zés annak ellenére feltünően jellemző, hogy éppen az $\ddot{o}$-ző területek kerültek a 16. században török uralom alá, s ezáltal az ilyen nyelvi sajátosságot mutató kódexek pusztulhattak el a legnagyobb mennyiségben. Mindezzel BÁRCZI maga sem állítja, hogy ekkoriban már beszélhetünk kialakult, normává rögzült $\ddot{o}$-ző típusú írott nyelvről, hiszen maguk az $\ddot{o}$-ző kódexek sem egyöntetűek az $\ddot{o}$-zés szempontjából, sőt az $\ddot{o}$-zés igen különböző fokai vannak bennük képviselve. Úgy véli azonban, hogy ezek a nyelvemlékek az $\ddot{o}$-zésnek a kolostori nyelvben történő terjedését mutathatják (1963/1975: 189). ${ }^{5}$

\footnotetext{
${ }^{3}$ Kivételt ez alól talán csak a Halotti beszéd Könyörgés része jelent, ami szó szerinti fordításával magától a Halotti beszédtől is elüt (KISS J. 2018: 365).

${ }^{4}$ Véleménye szerint ez egyrészt az írásbeliségnek a maihoz viszonyított igen szerény fokával, illetve elenyésző társadalmi funkciójával állhat összefüggésben, másrészt a nyelvi egységesülés igényének hiánya az akkori nyelvjárások közötti különbségek szerény mértékéből is következhetett (BÁRCZI 1963/1975: 185-186, 1967/2002: 520, vö. még Kiss J. 2018: 363).

${ }^{5} \mathrm{Az} \ddot{o}$-zés területi sajátosságait és presztízsét a későbbiekben nagyban befolyásolta, hogy a törökdúlás eredményeképpen a déli, főleg $\ddot{o}$-ző területek lakossága erősen megritkult részben a háborús pusztítások, részben a lakosság elvándorlása miatt, a hódoltság megszünése után pedig a nyelvterület népfölösleggel bíró részeiről, így a felvidéki és a dunántúli területekröl ellenkező irányú migrációs folyamatok indultak el erre a területre (BENKÖ 1957: 84-85, JUHÁSZ 2018: 332).
} 
A másik — kifejezetten a szórványok írásmódját is érintő — kezdemény BÁRCZI GÉZA véleménye szerint a királyi kancelláriához kötődött, amely a saját gyakorlatában egységes hangjelölési rendszert alakított ki, sőt éppen ennek révén a szóalakok egységesítésére is törekedett (1963/1975: 189). Ez utóbbi kijelentését azonban BÁRCZI konkrét példákkal nem támasztja alá. Nyelvtörténeti ismereteink alapján ugyanakkor nemcsak arra következtethetünk, hogy mely sajátosságok váltak a szórványemlékekben az írásszokások által bizonyos mértékig kedveltté a korban, hanem egyúttal az is valószínüsíthető némely esetben, hogy melyek azok a jelenségek, amelyek éppen a korabeli írásszokás következtében nem jelennek meg az írott forrásokban. Így például nyelvemlékeink tanúsága szerint nem volt szokás jelölni a kései ómagyar korban a középső nyelvállású rövid magánhangzók utáni, dentális mássalhangzók előtti $l$ hang kiesését vagy a nyugati nyitódó diftongizációt, noha ez utóbbira, egészen pontosan az é > ie változásra a nyelvterület nyugati részéről BÁRCZI szerint már a 15 . század elejéről idézhetünk példát. Az általa említett Sé településnév 1421-es Sye adatánál (lásd még Cs. 2: 793, Vas vm., ma: Sé, lásd VMFN. 114) azonban korábbi példát is találunk, Zala megyében ugyanis már a 14. század végén, 1391-ben Echyer formában tủnik fel Ecsér település neve (Cs. 3: 48). Van némi valószínüsége tehát annak, hogy a korszakban a nyugati nyitódó diftongizáció már élő nyelvjárási változat volt, de a lejegyzők esetleg nem találták azt az írott szöveghez méltónak (BÁRCZI 1963/1975: 188).

2.3. Azt is hozzá kell tennünk ugyanakkor, hogy a jelentősebb értelmiségi réteg megjelenése előtti korszakot illetően akár azt is feltételezhetjük, hogy a csekély számú írástudó ${ }^{6}$ által létrehozott írott anyag sokkal nagyobb mértékü egységet, következetességet mutathat, mint a későbbi korszakok termékei (vö. BENKÖ 1980: 81). Ebből a szempontból ugyancsak érdemes figyelmet fordítanunk a korai szövegemlékeinkre, illetve az okleveleken kívül más szórványemlékekre is, mivel azokban gyakran az oklevelekre is jellemzö írássajátosságokat tapasztalhatunk.

2.3.1. BENKŐ LORÁND szerint például a Halotti beszéd különösképpen kiemelkedik korai forrásaink közül hangjelölési rendszerének rendkívüli pontosságával és következetességével (BENKÖ 1980: 72, vö. még KIS T. 2018a: 37, 2018b: 58). A Halotti beszéd hangjelölésére vonatkozóan KIS TAMÁs is azt a következtetést vonja le a $v$ és $u$ grafémák szövegbeli alkalmazásának alapos vizsgálata révén, hogy legelső szövegemlékünkben igen nagy mértékủ anyanyelvi (fonológiai) tudatosságról valló betűhasználatot tapasztalhatunk (2018b: 71).

A Halotti beszéd mellett más Árpád-kori kis szövegemlékkel összefüggésben is megfogalmazódtak olyan elképzelések, amelyek a korszakra jellemző írássajátosságokkal kapcsolatosak. Így például azok enyhe fokú $\ddot{o}$-zése (illetve $\ddot{u}$-zése)

\footnotetext{
${ }^{6}$ TARNAI ANDOR feltételezése szerint például a 11-12. századi magyar írástudó elit mindössze 150200 főből állhatott (1981: 15, vö. még HoRvÁTH 2015: 19).
} 
alapján JUHÁSZ DEZSŐ úgy látja, hogy a kancelláriai norma bizonyos szinten a labiális változatok használatát támogathatta (például HB. zumtuchel [szömtökel

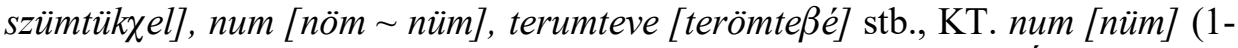
szer), de nem (3-szor), KTSz. mendun [mëndön], leluc [lélök] stb., ÓMS. thekunched [teküncsed], werud [véröd] stb., GyS. keguґlege [këgyössége], kuner [könyér], de kerezt [kërëszt], tiftes [tisztës] stb.) (2018: 324). ${ }^{7}$ A korai kis szövegemlékek magas szintű nyelvi és írásbeli állapotát jelzi BENKÖ LORÁND szerint többek között az is, hogy azokban — a korban már minden bizonnyal érvényesülő — alkalmi mássalhangzó-hasonulások nincsenek jelölve (1980: 81).

2.3.2. Szintén ide vonható BENKÖ LORÁND felvetése Anonymus $\ddot{o}$-ző tulajdonneveinek hátterére vonatkozóan, mely szerint abban is valószínüsíthetően tudatos írásbeli törekvést kell sejtenünk. Bár korábbi írásában úgy vélekedik, hogy az $\ddot{o}$-ző formák használata mögött $\mathrm{P}$ mester saját $\ddot{o}$-ző nyelvjárásának ${ }^{8}$ érvényesítése húzódhat meg (1996: 230), később mégis inkább amellett érvel, hogy a nagyszámú $\ddot{o}$-ző tulajdonnév jelenlétét a gesztában valamiféle írásnorma követése eredményezhette (2003: 159). Úgy gondolja, hogy ezt az álláspontot egyfelől az a háttértényező támogatja, hogy Anonymus - mint tudjuk — a történeti hüség látszatára rendkívül sokat adott, s emiatt saját nyelvjárásának $\ddot{o}$-ző sajátosságait kevésbé engedte volna felszínre törni az ő korában ë-ző nyelvjárásokból származó $\mathrm{s}$ általa is jól ismert nevek leírásában. A kancelláriai norma kialakulásának kezdeteire következtethetünk JUHÁSZ DEZSÖ véleménye szerint is az Anonymus Gesta Hungarorumában felbukkanó ö-zö (pl. 17. hymusuduor [Hímösudvor], 32. zepur [Szepös], 50. uert(us) [Vértös], 56. urcun, vrcun [Örkön 'Örkény'], ë-zö (pl. 28. zeguholmu [Szëgüholmu 'Szeghalom']) és váltakozó formák (pl. 19., 5051. velec [Velëk], de 20-21. veluc, ueluc [Velök], 44. temel, temes [Temës], de 11. tem(us) [Temös]) jelenlétéböl (2018: 324).

2.3.3. Másfelöl BENKÖ LORÁND szintén fontos körülményként tekint ebben a kérdésben arra, hogy a 12-13. század általános oklevélírói gyakorlatában is terjedőben volt az ë-ző területekről származó tulajdonnevek ö-ző írásszokása (lásd pl. 1219/1550:Zemlu(m), 1221/1550: Sumtey, 1226: Wertus, 1332: Scepus, 1285: Vrkun, 1317: Egur, 1323: Thumuswar), s ezért úgy véli, hogy a Magiszter alkalmazkodhatott ehhez az írásgyakorlathoz, de mint tekintélyes kancellista maga is

\footnotetext{
${ }^{7}$ Az $\ddot{o}$-zés nyelvi státusza a középmagyar kortól tovább erősödött azáltal, hogy a déli, $\ddot{o}$-ző területekről a török elől menekülő lakosság olyan vidékeken is elterjesztette azt, ahol korábban nem volt jellemző a használata (JuHÁsz 2018: 332).

${ }^{8}$ Anonymus nyelvjárásának területiségéröl BENKÖ úgy nyilatkozik, hogy bár a gesztában több jel is árulkodik a mester tartózkodási helyeiről, $\ddot{o}$-ző nyelvjárásáról legföljebb csak közvetett ismereteink lehetnek. A geszta $\ddot{o}$-zésének területi hovatartozását ennek ellenére megpróbálja óvatosan kijelölni, mégpedig a nyelvterület nyugati és/vagy déli részéhez köti azt (2003: 159, de lásd 1996: 230, JuHÁsz 2018: 324).
} 
hozzájárulhatott annak formálódásához (BENKŐ 2003: 160). A BENKÖ által említett $\ddot{e}$-ző területekről származó tulajdonnevek $\ddot{o}$-ző írásszokásával kapcsolatban meg kell ugyanakkor azt is jegyeznünk, hogy vajon milyen szempontok alapján tarthatjuk ë-ző régióknak a korban az adott területeket, ha azokon a helynevek $\ddot{o}$ ző formában is felbukkannak (az említett példáknak ráadásul csak egy része sorolható valóban a $12-13$. századhoz).

Az írásszokások kialakulása elsősorban természetesen helyesírási téren jelentkezett a korban, mivel az írástudás birtoklása a középkorban magas fokú müveltséget feltételezett, és az írásbeli szövegalkotással hivatásszerüen foglalkozók profizmusa egyfelöl a helyes írásra való törekvést jelentette (JUHÁSZ 2018: 315 316). HORVÁTH IVÁN szintén úgy vélekedik, hogy a korban már kialakulhattak „elemi helyesírási egyezmények”, amelyek azonban még nem országos hagyományon, legfeljebb helyi megszokásokon alapultak (2015: 23). Ez alapján talán a kialakuló írásszokásnak a helyesírás terén felbukkanó érvényesülését sejthetjük amögött, hogy a korai ómagyar korban az é hang hosszúságát bizonyos esetekben (bár többnyire következetlenül, lásd erről BÁBA 2018) feltehetően német mintára (KOROMPAY 2003: 289) az ee betükapcsolat is jelölhette, sőt bizonyos nevek, névrészek vagy akár közszavak írásmódjában valamilyen oknál fogva (talán azok egy szótagos volta miatt) más elemekhez képest kifejezetten kedvelt volt ez a fajta írásmód (a hivatalos névhasználat lehetőségét KENYHERCZ RÓBERT ugyancsak felveti, 2016: 18). KNIEZSA ISTVÁN hívja fel arra a figyelmet, hogy a Kér, Nyék, Szécs, Bél, Hét, Pél, Lég, Péc nevek vagy névrészek, valamint az ér köznév lejegyzésében igen gyakori, sőt általános az é hang ee-vel való jelölése (1952: 55-56). Ugyanilyen jellegzetes ez a megoldás a bérc földrajzi köznév és a szék névrészt tartalmazó nevek leírásában is (például bérc 1247: beerch, Hont, HA. 3: 33, Kisakasztó bérce 1329: Kysakazto beerchy, Kolozs, HA. 3: 53, Brizó bérce 1331/1394: Brizoubeerche, Hont, HA. 3: 34, Széklak 1237: Seecloc, Bács, KMHsz. 1: 254; Szék 1307: Zeek, Doboka, HA. 2: 26).

JUHÁSZ DEZSŐ véleménye szerint a kancellistáknak vagy a hiteles helyek írnokainak szakértelme a különböző szövegtípusok sablonjainak alkalmazásában is megnyilvánult. A korábbi ügyekben kibocsátott oklevelek formuláit tartalmazó segédkönyvekről és az oklevelek szerkesztését tanító tankönyvekről ÉRSZEGI GÉZA és SZENTPÉTERY IMRE is tesz említést. Ezek használata szükségszerü volt, hiszen egy-egy ilyen gyüjtemény „lehetővé tette a kancelláriának, hogy azonos ügyekben azonos formulákkal állíthasson ki oklevelet, megtakarítva ezzel az újrafogalmazás munkáját" (ÉRSZEGI 1998: 41, vö. még SZENTPÉTERY 1930: 25, 1942: 405, 410, HOFFMANN-RÁCZ-TÓTH 2018: 47). JUHÁSZ DEZSÖ szerint az írástudók a különböző tájak eltérő nyelvhasználatával is szembesültek, s többek között ez a fajta nyelvi tapasztalat, illetve az írásbeli hagyományozódáson alapuló 
sablonok alkalmazása vezetett együttesen ahhoz, hogy a korai írásmüvek az élőnyelvet egyfajta szürőn keresztül tükrözik (2018: 315-316). ${ }^{9}$

3. Az egyazon író tollából származó nyelvi ingadozásokhoz a fentiek mellett olyan tényezők is hozzájárulhatnak, amelyek a kialakulóban lévő írásszokástól függetlenek. Az ilyen módon létrejövő kettősségek adódhatnak az adott nyelvjárástípusban jelen lévő ingadozásokból is: a nyelvi változások természetes velejárója ugyanis az, hogy a régi és az új jelenség egy ideig mint szinkrón variációk egymás mellett élnek egyazon nyelvjárásban (BENKŐ 1957: 14, 1988: 63-64). A nyelvi jelenségek egymásmellettisége ráadásul az egyén (például az oklevélíró) nyelvhasználatában is feltétlenül megmutatkozik. Ezt a fajta „,fölvegyült nyelvjárásiasság"-ot — ami aztán az írásmüvekben is megjelenik — az adott szerző nemcsak a saját nyelvjárásának kettősségeiből „nyeri”, hanem adódhat ez a különböző tartózkodási helyein beszélt nyelvjárástípusok keveredéséből is (BENKŐ 1957: 37).

4. Nyelvemlékeink kevert nyelvi sajátosságai számos esetben abból a nyilvánvaló körülményböl fakadnak, hogy a kéziratok és a nyomtatványok gyakran nem eredeti formában maradtak fenn, vagyis bennük különböző egyének és esetleg különböző időszakok nyelvállapotának a keveredésével kell számolnunk. A kérdés a korai szövegemlékeink kapcsán is döntő jelentőségü (lásd ehhez BENKÖ 1980: 20-22, vö. még BÁRCZI 1963/1975: 186, N. FODOR 2008: 126, HORVÁTH 2015: 20), s nem kisebb súllyal esik latba a nyelvemlék eredetisége a jogi írásbeliség termékei esetében sem, hiszen a 11-12. századból származó okleveleink egy jelentős része csak későbbi másolat, átirat vagy hamisítvány formájában maradt fenn, ${ }^{10}$ ami természetesen jelentős mértékben befolyásolja azok nyelvjárástörténeti forrásértékét. Abban, hogy a 11-12. századból nagy számú bizonytalan kronológiai státuszú, ${ }^{11}$ vagyis másolt, átírt vagy hamis oklevél maradt fenn, számos tényező játszhat szerepet. Az átírás leggyakoribb indoka valószínúleg az oklevél megőrzésének a szándéka lehetett (amit az oklevelek szállítása, nem megfelelő

\footnotetext{
${ }^{9}$ Az írásbeliség normái ugyanakkor más szinteken is tetten érhetők az oklevélírásban. Úgy tünik például, hogy a szinonim helynevek esetében a névváltozatok közötti választást ugyancsak befolyásolhatta valamiféle írásszokáshoz való igazodás. Előfordulhat ugyanis, hogy bizonyos helynévvariánsok elterjedtségük és alacsony presztízsük miatt évszázadokon át rejtve maradnak az írásbeliség elött (KENYHERCZ 2016: 28). Az oklevelekben a latinizáló helynevek használata szintén az oklevél-szövegezők normatörekvésének egyik legfontosabb megnyilvánulása (HoFFMANN-RÁcZ-TóTH 2018: 49, 51).

${ }^{10}$ A 11. századból például mindössze négy eredeti oklevelet ismerünk; a többi, 11. századhoz köthető oklevél egy része későbbi másolatban maradt fenn, továbbá „,a magyar írásbeliség e korai időszakra datált okleveleinek egy másik jelentős részéről pedig — az erősödő kritikai szemléletnek is köszönhetően - bizonyosodott be, hogy valójában nem is a 11. században, hanem később, akár évszázadokkal később állították ki őket” (SzŐKE 2018: 419).

${ }^{11}$ A bizonytalan kronológiai státuszú oklevél kifejezéshez lásd SzŐKE 2015: 16.
} 
tárolási körülményei stb. veszélyeztethettek), de előfordulhatott például, hogy egy újabb vitás ügy kapcsán írták át és erősítették meg a korábbi jogi iratot. Vannak ugyanakkor eleve átírásra készült iratok is, amelyek királyi vagy egyéb méltóságok parancsait tartalmazták, $\mathrm{s}$ a parancs vagy utasítás teljesítése során az eljárásról készült oklevél kiállításakor az eredeti mandátumot mindenképpen átírták (KENYHERCZ 2016: 8, 21, vö. még ÉRSZEGI 1998: 40, HOFFMANN-RÁCZ-TÓTH 2018: 29). A hamis oklevelek keletkezéséhez elsősorban az a körülmény járulhatott hozzá, hogy az írásbeliség a 11. században egész Európában háttérbe szorult, a magyar nyelvterületen pedig a szóbeliség uralkodó helyzete folytán ekkoriban még el sem terjedt. Az eredeti oklevelek hiányának a következménye pedig az volt, hogy a 13. században, amikor viszont már szükségessé vált az írott bizonyítékok bemutatása egy-egy peres ügy során, nagy számban jelentek meg a hamisítványok, amelyek ugyan többnyire a valós birtokviszonyokat rögzítették, az is előfordult azonban, hogy az ilyen iratok célja a tulajdonjog meghamisítása volt (SZÖKE 2015: 18, 2017: 138, 2018: 428).

Az, hogy a másolt nyelvemlék nyelvi anyaga milyen mértékben mutat keveredést, attól sem választható el persze, hogy a változtatás lehetőségével a másolók vagy átírók milyen mértékben éltek. Ebben a tekintetben mind az oklevelek, mind a kódexek másolói között jelentős különbségeket fedezhetünk fel. Az okleveleket illetően SZENTPÉTERY tesz fontos megjegyzést a másolói kéz beavatkozásának mértékére vonatkozóan: véleménye szerint az átiratok helyességére leginkább a pápai átiratokban ügyeltek, de a hiteleshelyek is gondosabb átiratokat bocsátottak ki, mint azt a királyi kancellária gyakorlatában láthatjuk (SZENTPÉTERY 1942: 402, 419, KENYHERCZ 2016: 14, HOFFMANN-RÁCZ-TÓTH 2018: 29). ${ }^{12}$

Az sem lényegtelen részlet természetesen, hogy az adott kéziratot hányszor másolta eltérő személy, kézenfekvő ugyanis, hogy a nyelvemlék nyelvi sokszínüsége annál valószínübb, minél több szerző hagyta rajta a nyelvi lenyomatát (SZENTPÉTERY 1942: 410). Az efféle módosulásokról, ingadozásokról pedig azt is tudjuk, hogy azok elsősorban hangtani (és helyesírási) téren jelentkeznek (BENKÖ 1957: 43, SZÖKE 2010: 95, 98, 2011: 60, KENYHERCZ 2016: 10). KENYHERCZ RÓBERT szerint a hangtani jellegü eltérések gyakorisága azzal is összefüggésben lehet, hogy az ilyenfajta kettősségek feltehetően nem okoztak gondot az oklevelek kiállítása, átírása, illetve későbbi használata során, mivel ezeket nem tekintették olyan jellegü különbségeknek, amelyek az oklevelek jogi hitelét akár kis mértékben is megingathatták volna (2016: 13). Az átiratok ellenörzése során az oklevél jogi hitelét nem befolyásoló eltérések figyelmen kívül hagyását jól mutatja az is, hogy ilyen különbségeket nemcsak a tulajdonnévi szórványok írásmódjában, hanem magában a latin szövegben is találhatunk (KENYHERCZ 2016: 16).

${ }^{12}$ Az átírt és az átíró oklevél közötti eltérések okairól lásd KENYHERCZ 2016: 16, 34. 
KENYHERCZ RÓBERT egy további, nyelvjárástörténeti szempontból is fontos összefüggésre világít rá akkor, amikor a Szepes vármegyei birtokokat és birtokosaikat érintő ügyekben oklevélkibocsátó szervként müködő szepesi káptalan átíási gyakorlatát tárgyalja (2016: 17). Leírásából az derül ki ugyanis, hogy az itt müködő hiteleshely más hiteleshelyek gyakorlatához hasonlóan kétféle oklevelet — bevallást és jelentést — állított ki, s mindkét típus tartalmazhatott átírásokat. Csakhogy míg a bevallások többnyire régebbi, akár több száz évvel korábbi oklevelek szövegét másolták át, addig a jelentések gyakran az eredeti oklevél kiállításával azonos évben keletkeztek. Ilyen módon ez utóbbiak egymással történő összevetése nyelvtörténeti szempontból érthető módon kevesebb figyelmet kapott annak ellenére, hogy „ezek esetében is ugyanúgy egy más helyen, más kéztől kiállított korábbi irat szövege került bele egy újonnan szerkesztett oklevélbe" (KENYHERCZ 2016: 20). KENYHERCZ RÓBERT szerint ezek az oklevelek éppen azért különösen alkalmasak az oklevélátírási gyakorlat sajátosságainak megismerésére - amiért mellesleg együttes használatuknak, összevetésüknek csekély a nyelvtörténeti hasznosíthatósága - , mert esetükben nem kell azzal a nyelvi bizonytalansággal számolnunk, ami máskor a szórványoknak az eredeti vagy az átírt oklevél idejére való vonatkoztatását jelenti (2016: 17-21). A nyelvjárástörténeti vizsgálatok számára szintén fontos adalékul szolgálhatnak az ilyen természetủ átírások nemcsak közvetve mint az oklevélátírás megismerésének elsődleges forrásai, hanem akár közvetlenül is mint olyan nyelvemlékek, amelyek által bizonyos esetekben akár nyelvjárási különbségek nyomaira is bukkanhatunk.

Azt, hogy az egyazon vagy közel azonos évből származó (azonos ügyben születö) okleveleknek valóban lehet nyelvjárástörténeti szempontból hozadéka, N. FODOR JÁNOS kései ómagyar kori személynévi adatokon végzett vizsgálatai igazolják. Az általa összevetett egyazon ügyet tárgyaló (a Kállayak és Károlyiak közötti perről tudósító) négy oklevél közül három 1440-böl, egy pedig 1447-böl származik. N. FODOR JÁNOS szerint a Szatmár vármegye (1440), a Leleszi konvent (1440) és Hédervári Lőrinc nádor oklevelében (1447) szereplő nevek az Erzsébet királyné által kiadott oklevélre (1440) támaszkodnak, mégis számos helyen eltérés tapasztalható közöttük. A négy oklevél jobbágynevei között a labiális-

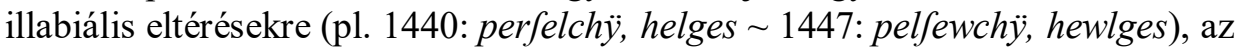
$i \sim e ́$ szembenállásra (pl. 1440: vÿkas $\sim$ vekas), valamint az $i \sim e \ddot{e}$ kettősségre (pl. 1440: kÿnches $\sim$ kenches) utaló jeleket egyaránt találunk (2008: 131-132). Ezek a kései ómagyar kori személynévi példák arra engednek következtetni, hogy a korai ómagyar kori nyelvjárástörténeti szembenállások tanulmányozásakor szintén termékeny kiindulópont lehet az egyazon vagy közel azonos évből származó, egymással kapcsolatban lévő oklevelek helynévi adatainak elemzése, hiszen általuk az oklevélkibocsátó helyek oklevélírói gyakorlatára vonatkozó megállapításokat fogalmazhatunk meg. 
A nem eredetiben fennmaradt (vagyis a hamis, az interpolált és az átírt) oklevelek adatainak nemcsak adott területhez, hanem más esetekben az időhöz kötése is meglehetősen bizonytalan (lásd ehhez SZAMOTA 1895: 129, JAKUBOVICH-PAIS 1929: XXIV, KENYHERCZ 2016: 9, HOFFMANN-RÁCZ-TÓTH 2018: 29), ezért azok tüzetesebb vizsgálata megkerülhetetlen nemcsak a kérdéses oklevél kronológiai rétegeinek a szétválasztásához, hanem egyúttal az ómagyar kori nyelvjárási különbségek leírásához is. A labiális-illabiális szembenállások vizsgálatakor például külön figyelmet érdemelnek az olyan adatok, mint a garamszentbenedeki apátság alapítóleveléből való Geletnek településnév korai labiális formájának felbukkanása $(1075 /+1124 /+1217$ : aliis tribus villis, scilicet Goznucha, Gelednuk et Kerestur, Gy. 1: 444, DHA. 1: 218). A Gelednuk formát GYÖRFFY GYÖRGY és SzŐKE MELINDA véleménye alapján nem köthetjük a 11. századhoz, az csak a későbbi interpoláció eredményeként került a szövegbe (DHA. 1: 216, 217; SzÖKE 2015: 98-99, vö. még DUDÁs 2004: 169). Valószínüleg szintén az átírás következményének tarthatjuk a Csépánfölde és a Csehtelek helynevek labialitásbeli módosulását a következő adatokban: +?1248>1393: Chepanfelde, +?1248>1394: Chepanfelde, +?1248>1402: Chepanfulde (Bereg vm., KMHsz. 1: 74); Csehtelek 1257/1390/1454: Cheh Thelek, 1257/1390/1494: Chehtelewk (Kraszna vm., Gy. 3: 511). A hangtani jellegü módosulások következetlenségét (és azoknak az oklevél jogi hitelét nem befolyásoló jellegét) ugyanakkor jól mutatja az a körülmény, hogy ugyanebben az oklevélben az átírás során a Györiteleke, Györkteleke név a labializáció szempontjából nem módosult: 1257/1390/1454: Gywry Theleke, 1257/1390/1494: Gywrkthelekhe (Gy. 3: 512). Ezek a példák tehát arra figyelmeztetnek bennünket, hogy a hangtani természetü nyelvjárási különbségek leírásakor az ilyen típusú oklevelek bizonyos adatait nem vonatkoztathatjuk az eredeti oklevelek keletkezési idejére.

7. A korai ómagyar kori oklevelek kevert nyelvi jellegét befolyásoló tényezőket a fentiek értelmében nem pusztán elméleti síkon szükséges figyelembe vennünk. Az eddigiek ismeretében több olyan további kutatási irányvonal, illetve szempont jelölhetö ki ugyanis, aminek a nyelvjárástörténeti sajátosságok leírásában meghatározó jelentősége lehet.

Egyfelől fontos szem előtt tartanunk azt a felismerést, mely szerint már a korai ómagyar kori források adatainak heterogenitását is alakíthatták a korban bizonyos tekintetben érvényesülő íráshagyományok. Annak ellenére vélekedhetünk így, hogy a források kevertnyelvüsége kapcsán a 15-16. század fordulójától kell igazán hangsúlyos tényezőként tekintenünk az egyre erőteljesebben jelentkező írásszokásokhoz való igazodásra (lásd ehhez BENKŐ 2003, JUHÁSZ 2018, KIS 2018a, 2018b). Ennek az irányelvnek az előtérbe helyezése különösen fontos lehet a kialakuló írásszokások révén gyakoribbá vált nyelvi jelenségek leírása esetében. Így például a korai ómagyar kori labiális-illabiális szembenállás területi sajátosságainak elemzése során az olyan, labiális adatokban bővelkedő területek (pl. Nyitra 
vármegye) adatainak többszempontú — tehát a településtörténeti mozzanatok mellett az írásszokások hatását is figyelembe vevő — vizsgálata szükséges, amelyek a későbbi korokban erőteljes illabialitást mutatnak (lásd ehhez BÁBA 2019).

Másfelől az adatok differenciáltabb kezelését teszik lehetővé a nem eredetiben fennmaradt forrásoknak a közelmúltban készült alapos nyelvtörténeti-névtörténeti elemzései. Az ilyen típusú oklevelek mélyreható filológiai analízisei ugyanis sok esetben hozzájárulhatnak a nyelvjárástörténeti (és egyidejűleg a hang- és helyesírás-történeti) vizsgálatok pontosításához. Ez azt is jelenti egyúttal, hogy a hangtani irányultságú nyelvjárástörténeti elemzések eredményei (például bizonyos nyelvjárástörténeti sajátosságok kronológiai határainak kijelölése) egyfajta keresztszempontként szintén hasznos adalékokkal szolgálhatnak a bizonytalan kronológiai státuszú oklevelek adatainak kronológiai síkokhoz kötésében.

\section{Irodalom}

BÁBA BARBARA 2018. Módszertani problémák az ómagyar kori hangtani nyelvjárási különbségek leírásában. Magyar Nyelvjárások 56: 89-102.

BÁBA BARBARA 2019. Az $i \sim \ddot{u}$ szembenállás területi és kronológiai sajátosságai a korai ómagyar korban. In: FoRgÁCS TAMÁs-NÉMETH MIKLÓS-SINKOVICS BALÁZS szerk. A nyelvtörténeti kutatások újabb eredményei 10. Szeged, Szegedi Tudományegyetem, Magyar Nyelvészeti Tanszék. 7-18.

BÁRCZI GÉZA 1963/1975. A magyar nyelv életrajza. Harmadik kiadás. Budapest, Gondolat Kiadó.

BÁRCZI GÉZA 1967/2002. Bevezetés. In: BÁRCZI GÉZA-BENKŐ LORÁND-BERRÁR JOLÁN szerk. A magyar nyelv története. Budapest, Nemzeti Tankönyvkiadó. 7-19.

BENKÖ LORÁND 1957. Magyar nyelvjárástörténet. Budapest, Tankönyvkiadó.

BENKÖ LORÁND 1980. Az Arpád-kor magyar nyelvü szövegemlékei. Budapest, Akadémiai Kiadó.

BENKŐ LORÁND 1988. A történeti nyelvtudomány alapjai. Budapest, Tankönyvkiadó.

BENKÖ LORÁND 1996. Anonymus élő nyelvi forrásai. In: KovÁCs LÁSZLÓ-VESZPRÉMY LÁSZLÓ szerk. A honfoglaláskor írott forrásai. Budapest, Balassi Kiadó. 221-247.

BENKÖ LORÁND 2003. Beszélnek a múlt nevei. Tanulmányok az Árpád-kori tulajdonnevekröl. Budapest, Akadémiai Kiadó.

Cs. = CsÁNKI DEZSÖ 1890-1913. Magyarország történeti földrajza a Hunyadiak korában I-III., $V$. Budapest, Magyar Tudományos Akadémia.

DHA. = GYÖRFFY GYÖRGY szerk. 1992. Diplomata Hungariae Antiquissima. Vol. I. Budapest, Akadémiai Kiadó.

DUDÁS GYÖRGYI 2004. A szóvég felől induló labializáció az ómagyar korban. Helynévtörténeti Tanulmányok 1: 167-182.

N. FODOR JÁNOS 2008. Északkelet-Magyarország személyneveinek komplex nyelvi elemzése (1401-1526). Kézirat. Doktori értekezés. Budapest. 
ÉRSZEGI GÉZA 1998. Írásbeliségünk korai emlékei. Kis magyar oklevéltan. Rubicon 9-10: 38-44.

Gy. = GYÖRFFY GYÖRGY 1963-1998. Az Árpád-kori Magyarország történeti földrajza $I-I V$. Budapest, Akadémiai Kiadó.

HA. 1-4. = HOFFMANN ISTVÁN-RÁCZ ANITA-TÓTH VALÉRIA 1997, 1999, 2012, 2017. Helynévtörténeti adatok a korai ómagyar korból. 1. Abaúj-Csongrád vármegye. 2. Doboka-Györ vármegye. 3. Heves-Küküllö vármegye. 4. Liptó-Pilis vármegye. Debrecen, Debreceni Egyetemi Kiadó.

HOFFMANN ISTVÁN-RÁCZ ANITA-TÓTH VALÉRIA 2018. Régi magyar helynévadás. A korai ómagyar kor helynevei mint a magyar nyelvtörténet forrásai. Budapest, Gondolat Kiadó.

HORVÁTH IVÁN 2015. Ómagyar szövegemlékek mint textológiai tárgyak. Budapest, Országos Széchényi Könyvtár.

JAKUBOVICH EMIL-PAIS DeZsö 1929. Ó-magyar olvasókönyv. Pécs, Danubia.

JUHÁSz DEZSŐ 2018. A nyelvjárások történetéből. In: KISS JENŐ-PuSZTAI FERENC szerk. A magyar nyelvtörténet kézikönyve. Budapest, Tinta Könyvkiadó. 314-349.

KENYHERCZ RÓBERT 2016. A középkori oklevelek átírási gyakorlatának nyelvtörténeti vonatkozásai. Helynévtörténeti Tanulmányok 12: 7-44.

KISS JENŐ 2018. A magyar köznyelv (standard) alakulástörténetéhez. In: KISS JENŐPUSZTAI FERENC szerk. A magyar nyelvtörténet kézikönyve. Budapest, Tinta Könyvkiadó. 361-377.

KIS TAMÁs 2018a. A Halotti beszéd paleográfiája és betühü átiratai. Magyar Nyelvjárások 56: 37-56.

KIS TAMÁs 2018b. Megjegyzések a Halotti beszéd $u$ és $v$ betüinek hangértékéröl. Magyar Nyelvjárások 56: 57-74.

KMHsz. $=$ HOFFMANN ISTVÁN szerk. 2005. Korai magyar helynévszótár 1000-1350. I. Abaúj-Csongrád vármegye. A Magyar Névarchívum Kiadványai 10. Debrecen, Debreceni Egyetem Magyar Nyelvtudományi Tanszéke.

KNIEZSA ISTVÁN 1952. Helyesirásunk története a könyvnyomtatás koráig. Budapest, Akadémiai Kiadó.

KOROMPAY KLÁRA 2003. Helyesírás-történet. In: KISS JENŐ-PUSZTAI FERENC szerk. Magyar nyelvtörténet. Budapest, Osiris Kiadó. 281-300, 579-595.

SZAMOTA ISTVÁN 1895. A tihanyi apátság 1055-iki alapítólevele mint a magyar nyelv legrégibb hiteles és egykorú emléke. Nyelvtudományi Közlemények 25/2: $129-165$.

SZENTPÉTERY IMRE 1930. Magyar oklevéltan. Budapest, Magyar Történelmi Társulat. SZENTPÉTERY IMRE 1942. A középkori oklevélátiratok hibáinak elemzése. In: Emlékkönyv Melich János hetvenedik születésnapjára. Budapest, Magyar Nyelvtudományi Társaság. 401-423.

SzŐKE MELINDA 2010. A garamszentbenedeki alapítólevél nyelvtörténeti forrásértékéröl. Helynévtörténeti Tanulmányok 5: 95-103.

SzŐKE MELINDA 2011. A garamszentbenedeki apátság 1075. évi alapítólevelének kronológiai rétegei. Helynévtörténeti Tanulmányok 6: 59-65. 
SzÖKE MELINDA 2015. A garamszentbenedeki apátság alapitólevelének nyelvtörténeti vizsgálata. A Magyar Névarchívum Kiadványai 33. Debrecen, Debreceni Egyetemi Kiadó.

SzŐKE Melinda 2017. A Bakonybéli alapítólevél birtokneveiröl. Magyar Nyelvjárások 55: 137-151.

SzŐKE MELINDA 2018. A hamis oklevelek a magyar nyelvtörténeti vizsgálatok szemszögéböl. Századok 152: 419-434.

TARNAI ANDOR 1981. A kezdetektöl a felvilágosodásig. In: SöTÉR ISTVÁN szerk. A magyar kritika évszázadai. I. Rendszerek. Budapest, Szépirodalmi Könyvkiadó. $11-247$.

VMFN. = BALOGH LAJOS-VÉGH JÓZSEF szerk. 1982. Vas megye földrajzi nevei. Szombathely, Vas Megyei Múzeumok Igazgatósága.

\section{On the Mixed Linguistic Status of Charters in View of Studies in Historical Dialectology}

Since the Old Hungarian Era, the primary and direct source of studies in historical dialectology have been represented, besides some other points of orientation, by data found in linguistic records. The source value of data in linguistic records in historical dialectology, however, may vary significantly. In this paper I address only one aspect of this complex issue, namely the mixed linguistic status of charters and its role in the process of research in historical dialectology.

The normative rules emerging explicitly mostly after the turn of the $15^{\text {th }}$ and $16^{\text {th }}$ centuries resulted in the mixed linguistic status of several Hungarian linguistic records. This is related to the fact that the emerging literary norm can only partly suppress the author's own linguistic status in most of the cases, which results in numerous fluctuations, and in several cases even hypercorrection. Although we can talk about the actual standardization of the Hungarian written vernacular only from the $16^{\text {th }}$ century, several signs indicate that we can already talk about the emergence and sporadic presence of some kind of a written tradition in connection with the Old Hungarian Era. Thus, for example, at the end of the Old Hungarian Era, the spreading of the use of $\ddot{o}$ in monastery language can be shown by certain codices using $\ddot{o}$. Ideas referring to written features typical of the era have been expressed in connection with the Funeral Sermon and other records from the Árpád Era also, as well as Anonymus' Gesta Hungarorum: based on their slight use of the $\ddot{o}$ (and $\ddot{u}$ ), it seems that to a certain extent the developing written tradition preferred the use of the labial variations.

Such factors could also contribute to the linguistic fluctuations of the same author that are independent of the developing written tradition. Such dualities may come, for example, from the fluctuations present in the given type of dialect as well: as it is a natural feature of linguistic changes that the old and new phenomena co-exist for a while as synchronous variations within the same dialect. 
The mixed linguistic features of our linguistic records are due to the fact that manuscripts and documents often did not survive in their original form, thus in this case we may consider the mixture of the linguistic status of different people and even different eras in them. This issue is crucial also in the case of our early records, while the originality of the record is also an important factor in the case of the products of legal written documents; this is because a significant part of our charters from the $11^{\text {th }}$ and $12^{\text {th }}$ centuries have survived only in the form of subsequent copies, transcripts or forgeries, which, of course, has a major influence on their source value in historical linguistics. 